\title{
TANDA DAN GEJALA PENYAKIT SERTA FAKTOR RESIKO PADA ANAK USIA SEKOLAH DI DESA KARIMBOW KECAMATANMOTOLING TIMUR: STUDI DESKRIPTIF
}

\author{
Thea Runtunuwu ${ }^{a^{*}}$, Billy J. Kepel ${ }^{\text {b }}$, Valen Fridolin Simak ${ }^{\mathrm{c}}$ \\ ${ }^{a b c}$ Program Studi Ilmu Keperawatan Fakultas Kedokteran Universitas Sam Ratulangi ${ }^{\mathrm{b}}$ Program Studi
}

\begin{abstract}
Epidemiologica transition that is happening in this world these days has caused changes in various diseases patterns, such as infectious diseases to non-infectious diseases. The increase of non-infectious diseases cases happens is related to an increase in risk factors due to lifestyle changes in line with the development of an increasingly modern world, population growth and increasing life expectancy. The purpose of this research is to determine the description of the signs and symptoms of diseases that occur in school age children. The method used in this research is descriptive method. Sampling in this study using total sampling. The data collection used by researchers is a questionnaire or questionnaire in accordance with the research objectives and refers to the conceptual framework that has been made. Collecting instruments of the sign and symptom questionnaire, and the risk factor questionnaire. With a total of 25 questions, in which there are questions about signs and symptoms of disease, 15 questions and risk factors for 10 questions. Results Based on the results of research conducted in Karimbow Village, Motoling Timur District, it was found that most of the respondents had signs and symptoms of cough, namely in the occasional category. And it was found that most of the respondents had a risk factor for exposure to cigarette smoke in the occasional category. The conclusion of the study of respondents to children in Karimbow Village had experienced the same signs and symptoms and risk factors.
\end{abstract}

Key word: sign and symptoms, children, clean and healthy behaviors

\begin{abstract}
Abstrak:Transisi epidemiologi yang terjadi di dunia saat ini telah mengakibatkan berbagai perubahan pola penyakit, yaitu dari penyakit menular ke penyakit tidak menular. Peningkatan kejadian penyakit tidak menular berhubungan dengan peningkatan factor resiko akibat perubahan gaya hidup seiring dengan perkembangan dunia yang makin moderen, pertumbuhan populasi dan peningkatan usia harapan hidup. Tujuan untuk mengetahui gambaran tanda dan gejala penyakit yang terjadi pada anak usia sekolah. Metode yang digunakan dalam penelitian ini adalah metode penelitian deskriptif. Sampel dalam penelitian ini adalah anak usia sekolah umur 6 - 12 tahun yang bersedia untuk menjadi responden. Pengambilan sampel dalam penelitian ini menggunakan total sampling.Pengumpulan data yang digunakan peneliti adalah kuesioner atau angket sesuai dengan tujuan penelitian dan mengacu pada kerangka konsep yang telah dibuat.Instrument pengumpulan dari kuesioner tanda dan gejala penyakit, dan kuesioner faktor resiko. Dengan jumlah pertanyaan 25 butir, yang di dalamnya ada pertanyaan mengenai tanda dan gejala penyakit 15 butir pertanyaan, dan factor resiko 10 butir pertanyaan. Hasil Berdasarkan hasil penelitian yang dilakukan di Desa Karimbow, Kecamatan Motoling Timur didapati bahwa sebagian besar responden memiliki tanda dan gejala batuk yaitu pada kategori kadang dan didapati bahwa sebagian besar responden memiliki factor resiko terpapar asap rokok pada kategori kadang juga. Kesimpulan penelitian responden pada anak-anak di Desa Karimbow pernah merasakan tanda dan gejala dan factor resiko yang sama.
\end{abstract}

Kata Kunci: tanda dan gejala, anak-anak, perilaku hidup bersih dan sehat (PHBS) 


\section{PENDAHULUAN}

Transisi epidemiologi yang terjadi di dunia saat ini telah mengakibatkan berbagai perubahan pola penyakit, yaitu dari penyakit menular ke penyakit tidak menular. Peningkatan kejadian penyakit tidak menular berhubungan dengan peningkatan factor resiko akibat perubahan gaya hidup seiring dengan perkembangan dunia yang makin moderen, pertumbuhan populasi dan peningkatan usia harapan hidup (Kemenkes RI, 2012). Penyakit menular timbul akibat dari beroperasinya berbagai factor, baik dari agen atau lingkungan.Bentuk ini tergambar di dalam istilah yang dikenal luas dewasa ini yaitu penyebab majemuk (multiple causation of disease) sebagai lawan dari penyebab tunggal (single causation).Dalam epidemiologi ada tiga factor yang dapat menerangkan penyebaran penyakit atau masalah kesehatan yaitu orang (person), tempat (place), dan waktu (time).Ini dapat digunakan untuk menggambarkan adanya perbedaan keterpaparan dan kerentanan.Perbedaan ini bisa digunakan sebagai petunjuk tentang sumber, agen yang bertanggung jawab, transisi dan penyebaran suatu penyakit (Irwan. 2017).

Penyakit tidak menular (PTM) adalah penyakit atau kondisi medis yang tidak dapat ditularkan dari satu individu ke individu lainnnya.Berdasarkan data WHO, PTM merupakan penyebab dari $68 \%$ kematian di dunia pada tahun 20212.Diprediksi, PTM merupakan tantangan dalam dunia kesehatan (Cindy, 2015).Irwan.(2017) Karakteristik penyakit

Pathogenitas agent merujuk pada kemampuan atau kapasitas agent penyakit dalam menyebabkan sakit pada host, karakteristik lain dari agent tidak menular yang penting untuk diperhatikan adalah: Kemampuan menginvasi atau memasuki jaringan, kemampuan merusak jaringan: reversible dan irreversible, kemampuan menibulkan reaksi hipersensitif (Irwan, 2017). Studi pendahuluan juga dilakukan di Desa Karimbow melalui telepon dengan menular secara umum memiliki gejala klinik yang berbeda-beda sesuai dengan factor penyebab penyakit tersebut. Berdasarkan manifestasi klinik maka karakteristik penyakit menular terdiri dari : Spectrum penyakit menular, pada proses penyakit menular secara umum dijumpai berbagai manifestasi klinik, mulai dari gejala klinik yang tidak tampak sampai keadaan yang berat disertai kompilkasi dan berakhir cacat atau meninggal dunia. Akhir dari proses penyakit adalah sembuh, cacat atau meninggal.

Infeksi terselubung (tanpa gejala klinis), adalah keadaan suatu penyakit yang tidak menampakan secara jelas dan nyata dalam bentuk gejala klinis yang jelas sehingga tidak dapat di diagnosa tanpa cara tertentu. Sumber penularan, merupakan media yng menjadikan suatu penyakit tersebut bisa menyebar kepada seseorang. Sumber ini meliputi: Penderita, pembawa kuman, binatang sakit, tumbuhan atau benda dan cara penularan. Karakteristik penyakit tidak menular yaitu, agent dapat merujuk pada non living agen, yakni kimiawi, fisik, mekanik dan psikis, agent penyakit tidak menular terdiri dari berbagai macam karakteristik, mulai dari yang paling sedehana hingga yang bersifat sangat komplek, contohnya molekul hingga zat dengan ikatan yang kompleks, mengetahui spesifikasi dari agent diperlukan untuk memberikan penjelasan lengkap tentang penyakit tidak menular, suatu agent tidak menular menyebabkan tingkat keparahan yang bervariasi (dinyatakan dalam skala pathogenitas).

Kepala Desa dan petugas kesehatan yang ada di Desa.Dan didapati jumlah keseluruhan anak sekolah dasar yang bersekolah di Desa Karimbow berjumlah 139 siswa, yang bersekolah diluar Desa Karimbow berjumlah 10 orang. Jadi total anak usia sekolah dasar di Desa Karimbow berjumlah 149 anak, beberapa diantaranya sering mengeluh terjadi gangguan dalam bernafas, batuk-batuk, merasakan 
gangguan di pencernaan dan sering kehilangan nafsu makan.

\section{METODE PENELITIAN}

Metode yang digunakan dalam penelitian ini adalah metode penelitian deskriptif. Penelitian ini dilakukan di wilayah Desa Karimbow, Kecamatan Motoling Timur, Sulawesi Utara. Populasi dalam penelitian ini adalah anak usia sekolah yang berumur $6-12$ tahun yang tinggal di wilayah Desa Karimbow, Kecamatan Motoling Timur dengan total 149 anak. Sampel dalam penelitian ini adalah anak usia sekolah umur 6 - 12 tahun yang bersedia untuk menjadi responden. Pengambilan sampel dalam penelitian ini menggunakan total sampling.

Kriteria inklusi adalah karakteristik umum subyek penelitian pada populasi target dan populasi terjangkau (Nursalam, 2013). Kriteria inklusi dalam penelitian ini adalah anak usia sekolah umur 6 - 12 tahun di Desa Karimbow, Kecamatan Motoling Timur dan bersedia menjadi responden. Kriteria eksklusi adalah anak usia sekolah yang tidak mengisi kuesioner dalam google form pada saat penelitian.

Pengumpulan data yang digunakan peneliti adalah kuesioner atau angket sesuai dengan tujuan penelitian dan mengacu pada kerangka konsep yang telah dibuat. Instrumen pengumpulan dari kuesioner tanda dan gejala penyakit, dan kuesioner faktor resiko. Dengan jumlah pertanyaan 25 butir, yang di dalamnya ada pertanyaan mengenai tanda dan gejala penyakit 15 butir pertanyaan, dan factor resiko 10 butir pertanyaan. Dengan menggunakan Skala Likert yang terdiri dari 4 pilihan jawaban yaitu SL (Selalu), S (Sering), K (Kadang), TP (Tidak pernah). Dengan skor SL: 4, S: 3, KK: 2, TP: 1.

Pengambilan data yang dilakukan dengan membagikan link (https://forms.gle/vFXAy2DHsR1fs2PH6) kepada responden yang dalam hal ini akan di dampingi langsung oleh orang tua atau wali orang tua dalam pengisian kuesioner yang ditaruh di dalam google form. Dan apabila data telah terkumpul, kemudian akan dilakukan pengolaan data, disajikan dan di analisis.

\section{HASIL}

Berdasarkan hasil temuan peneliti selama melakukan penelitian di Desa Karimbow, didapati jumlah responden sebanyak 149 orang dengan karakteristik responden berupa usia dan jenis kelamin.

Tabel 1. Distribusi Frekuensi Responden Menurut Usia Dan Jenis Kelamin

\begin{tabular}{|c|c|c|c|}
\hline No & Variabel & $\mathrm{f}$ & $\%$ \\
\hline \multicolumn{4}{|c|}{ 1. Jenis kelamin } \\
\hline & - Perempuan & 65 & 43,6 \\
\hline & - $\quad$ Laki-laki & 84 & 56,4 \\
\hline \multicolumn{4}{|c|}{ 2. Usia } \\
\hline & -6 & 22 & 14,8 \\
\hline & -7 & 16 & 10,7 \\
\hline & -8 & 22 & 14,8 \\
\hline & -9 & 26 & 17,4 \\
\hline & $\begin{array}{l}-\quad 10 \\
-10\end{array}$ & 21 & 14,1 \\
\hline & - 11 & 19 & 12,8 \\
\hline & - 12 & 23 & 15,4 \\
\hline
\end{tabular}


Jurnal Keperawatan, Volume 9, No. 1, Februari 2021, (Hal. 63-70)

Tabel di atas menunjukan bahwa dari total 149 responden, usia 9 tahun 26 orang $(17,4 \%)$, usia 12 tahun $(15,4 \%)$, usia 6-8 tahun 22 orang $(14,8 \%)$, usia 10 tahun 21 orang $(14,1 \%)$, usia 11 tahun 19 orang $(12,8 \%)$, dan usia 7 tahun jumlah 16 orang $(10,7 \%)$. Berdasarkan data pada table di atas dari total 149 responden, berjenis kelamin perempuan 84 orang $(56,4 \%)$ dan berjenis kelamin laki-laki 65 orang $(56,4 \%)$.

Tabel 2. Distribusi Frekuensi Responden Menurut Tanda dan Gejala

\begin{tabular}{|c|c|c|c|}
\hline No & Variabel & f & $\%$ \\
\hline 1. & $\begin{array}{l}\text { Gangguan Penciuman } \\
-\quad \text { Kadang } \\
-\quad \text { Selalu } \\
-\quad \text { Sering } \\
-\quad \text { Tidak pernah }\end{array}$ & $\begin{array}{c}53 \\
8 \\
42 \\
46\end{array}$ & $\begin{array}{c}35,6 \\
5,4 \\
28,2 \\
30,9\end{array}$ \\
\hline 2. & \begin{tabular}{ll}
\multicolumn{2}{l}{ Batuk } \\
- & Kadang \\
- & Selalu \\
- & Sering \\
- & Tidak pernah
\end{tabular} & $\begin{array}{c}63 \\
5 \\
44 \\
37\end{array}$ & $\begin{array}{c}42,3 \\
3,4 \\
29,5 \\
24,8\end{array}$ \\
\hline 3. & \begin{tabular}{ll}
\multicolumn{2}{l}{ Demam } \\
- & Kadang \\
- & Selalu \\
- & Sering \\
- & Tidak pernah
\end{tabular} & $\begin{array}{c}65 \\
4 \\
26 \\
53\end{array}$ & $\begin{array}{c}43,6 \\
2,7 \\
17,4 \\
35,6\end{array}$ \\
\hline 4. & \begin{tabular}{ll}
\multicolumn{2}{l}{ Sakit Kepala } \\
$-\quad$ Kadang \\
$-\quad$ Selalu \\
$-\quad$ Sering \\
$-\quad$ Tidak pernah
\end{tabular} & $\begin{array}{c}63 \\
1 \\
35 \\
50\end{array}$ & $\begin{array}{c}42,3 \\
7,0 \\
23,5 \\
33,6\end{array}$ \\
\hline 5. & \begin{tabular}{ll}
\multicolumn{2}{l}{ Nyeri Perut } \\
$-\quad$ Kadang \\
$-\quad$ Selalu \\
$-\quad$ Sering \\
$-\quad$ Tidak pernah
\end{tabular} & $\begin{array}{c}61 \\
6 \\
28 \\
54\end{array}$ & $\begin{array}{c}40,9 \\
4,0 \\
18,8 \\
36,2\end{array}$ \\
\hline 6. & $\begin{array}{ll}\text { Mual Muntah } \\
-\quad \text { Kadang } \\
-\quad \text { Selalu } \\
-\quad \text { Sering } \\
-\quad \text { Tidak pernah }\end{array}$ & $\begin{array}{c}52 \\
8 \\
21 \\
68\end{array}$ & $\begin{array}{c}34,9 \\
5,4 \\
14,1 \\
45,6\end{array}$ \\
\hline 7. & \begin{tabular}{ll}
\multicolumn{2}{l}{ Tinja Lembek } \\
$-\quad$ Kadang \\
$-\quad$ Selalu \\
$-\quad$ Sering \\
$-\quad$ Tidak pernah \\
\end{tabular} & $\begin{array}{c}65 \\
6 \\
24 \\
54\end{array}$ & $\begin{array}{c}43,6 \\
4,0 \\
16,1 \\
36,2\end{array}$ \\
\hline 8. & \begin{tabular}{ll}
\multicolumn{2}{l}{ Tinja Cair } \\
$-\quad$ Kadang \\
$-\quad$ Selalu \\
$-\quad$ Sering \\
$-\quad$ Tidak pernah
\end{tabular} & $\begin{array}{c}47 \\
6 \\
33 \\
63\end{array}$ & $\begin{array}{c}31,5 \\
4,0 \\
22,1 \\
42,3\end{array}$ \\
\hline 9. & $\begin{array}{l}\text { Kehilangan Nafsu Makan } \\
-\quad \text { Kadang } \\
-\quad \text { Selalu }\end{array}$ & $\begin{array}{c}67 \\
6\end{array}$ & $\begin{array}{c}45,0 \\
4,0\end{array}$ \\
\hline
\end{tabular}

Thea, Billy, Valen, TandaDanGejalaPenyakit... 
Jurnal Keperawatan, Volume 9, No. 1, Februari 2021, (Hal. 63-70)

\begin{tabular}{ccccc}
\hline No & & Variabel & f & \% \\
\hline & - & Sering & 26 & 17,4 \\
& - & Tidak pernah & 50 & 33,6 \\
& & & 100,0 \\
\hline
\end{tabular}

Tabel 3. Distribusi Frekuensi Responden Menurut Faktor Risiko

\begin{tabular}{|c|c|c|c|}
\hline No & Variabel & $\mathbf{f}$ & $\%$ \\
\hline \multirow[t]{5}{*}{1.} & Lingkungan Berdebu & & \\
\hline & - Kadang & 61 & 40,9 \\
\hline & - Selalu & 34 & 22,8 \\
\hline & - $\quad$ Sering & 48 & 32,2 \\
\hline & - Tidak pernah & 6 & 4,0 \\
\hline \multirow[t]{5}{*}{2.} & Asap Rokok & & \\
\hline & - Kadang & 75 & 50,3 \\
\hline & - Selalu & 17 & 11,4 \\
\hline & - $\quad$ Sering & 36 & 24,2 \\
\hline & - Tidak pernah & 21 & 14,1 \\
\hline \multirow[t]{5}{*}{3.} & Udara Panas & & \\
\hline & - Kadang & 54 & 36,2 \\
\hline & - Selalu & 36 & 24,2 \\
\hline & - Sering & 52 & 34,9 \\
\hline & - Tidak pernah & 7 & 4,7 \\
\hline \multirow[t]{5}{*}{4.} & Pola Makan & & \\
\hline & - $\quad$ Kadang & 44 & 29,5 \\
\hline & - Selalu & 36 & 24,2 \\
\hline & - $\quad$ Sering & 59 & 39,6 \\
\hline & - Tidak pernah & 10 & 6,7 \\
\hline \multirow[t]{5}{*}{5.} & Alergi Makanan & & \\
\hline & - Kadang & 65 & 43,6 \\
\hline & - Selalu & 14 & 9,4 \\
\hline & - $\quad$ Sering & 18 & 12,1 \\
\hline & - Tidak pernah & 52 & 34,9 \\
\hline \multirow[t]{5}{*}{6.} & Mencuci Tangan & & \\
\hline & - Kadang & 74 & 49,7 \\
\hline & - Selalu & 35 & 23,5 \\
\hline & - $\quad$ Sering & 34 & 22,8 \\
\hline & - Tidak pernah & 6 & 4,0 \\
\hline
\end{tabular}

\section{PEMBAHASAN}

\section{Tanda dan gejala penyakit}

Berdasarkan hasil penelitian tanda dan gejala penyumbatan hidung menunjukan bahwa sebagian besar responden memilih kategori kadang. Hal ini dikarenakan lingkungan udara yang bersih. Menurut Dwi Marliawaty (2016), mengatakan gejala hidung tersumbat dapat terjadi akibat adanya aliran udara yang terhambat dikarenakan rongga hidung yang menyempit. Hasil penelitian tetesan hidung memilih kadang dikarenakan lingkungan yang baik dan tidak berdebu. Hasil penelitian ini di dukung oleh Andre (2016), menunjukan bahwa pada pemeriksaan secret mukoid $(11,11 \%)$, secret serous $(5,56 \%)$, dan secret purulen $(5,56 \%)$.

Dari hasil penelitian tanda dan gejala batuk terbanyak yang memilih kadang hal ini dikrenakan karena responden jarang terpapar debu dan asap rokok yang dapat menyebabkan batuk. Menurut tamaweol (2016) batuk merupakan upaya pertahanan paru terhadap berbagai ransangan yang ada dan reflex fisiologis yang melindungi paru dari trauma mekanik, kimia dan suhu. Batuk menjadi patologis bila dirasakan 
sebagai gangguan. Batuk seperti itu sering merupakan tanda suatu penyakit di dalam atau diluar paru dan kadang berupa gejala awal dari suatu penyakit. Batuk merupakan gejala tersering penyakit pernapasan dan masalah yang sering kali dihadapi dr dalam praktik sehari-hari.

Hasil dalam penelitian ini didapati tanda dan gejaja demam terbanyak memilih kadang dikarenakan responden jarang bermain di udara atau lingkungan yang ekstrim. Demam adalah suatu reaksi yang mengambarkan adanya suatu proses dalam tubuh yang ditandai dengan adanya peningkatan suhu tubuh. (Arifianto \& Hariyadi 2019).

Hasil dalam penelitian ini didapati tanda dan gejala sakit kepala terbanyak memilih kadang. Hal ini dikarenakan responden jarang tidur larut malam, jarang bermain di udara yang panas, dan menjaga pola makan dengan baik. Menurut penelitian yang dilakukan oleh Leny Kurnia (2019), nyeri kepala adalah gangguan neorologis dengan penyebab yang bervariasi dan disebabkan oleh kelainan primer ataupun sekunder.

Hasil penelitian tentang tanda dan gejala nyeri perut terbanyak memilih kadang dikarenakan responden memperhatikan dengan baik pola makan mereka dan responden jarang terkena alergi makanan. Tapi penelitian ini tidak sejalan dengan penelitian yang dilakukan oleh Wibowo at al (2020) yang mendapatkan hasil perbandingan yang sama antara laki-laki dan perempuan, dan keluhan nyeri perut didominasi pada lama keluhan lebih dari 48 jam.

Hasil penelitian tanda dan gejala mual dan muntah terbanyak memilih yaitu tidak pernah. Hal ini karena responden jarang terkena alergi makanan. Penelitian ini tidak sejalan dengan penelitian yang dilakukan oleh Oktavia (2017), yang menunjukan $(75 \%)$ anak mengalami mual.

Hasil penelitian tanda dan gejala tinja lembek di atas menunjukan banyak memilih kadang dikarenakan responden jarang mencuci tangan. Menurut penelitian yang dilakukan oleh Maryanti et al. 2014 didapatkan hasil sebagian besar responden mempunyai status gizi baik dan didapatkan konstitensi sebagian besar tinja anak lembek.

Hasil penelitian tanda dan gejala tinja cair di atas menunjukan pilihan terbanyak yaitu tidak pernah dikarenakan status gizi responden baik. Berbanding terbalik dengan penelitian yang dilakukan oleh Maryanti et al (2014) ditemukan kejadian diare lebih banyak ditemukan pada anak laki-laki dibandingkan anak perempuan.

\section{Faktor Resiko}

Hasil penelitian factor resiko membersihkan rumah responden terbanyak memilih kadang.Dan penelitian ini berbanding terbalik dengan penelitian yang dilakukan oleh Lukas et al. 2019 membuktikan lebih dari separuh anak pra sekolah melakukan phbs sangat baik.

Berdasarkan hasil penelitian factor resiko terbanyak tentang lingkungan berdebu memilih kadang $(40,9 \%)$.

Berdasarkan penelitian faktor resiko asap rokok sebagian besar responden memilih kadang. Menurut Wardani et al (2016), anak-anak yang orang tuanya merokok lebih mudah terkena penyakit saluran pernafapasan seperti flu, asma, pneumonia dan penyakit saluran pernafasan lainnya. Dari penelitian ini juaga berbanding terbalik yaitu dengan mendapatkan hasil sebagian besar responden terpapar asap rokok.

Hasil penelitian factor resiko terbanyak tentang udara panas responden terbanyak yang memilih kadang. Menurut WHO (2016), pencemaran udara merupakan merupakan factor resiko gamgguan kesehatan terbesar di dunia, diperkirakan sekitar 6.5 juta orang meninggal akibat tiap bulan karena paparan polusi udara.

Berdasarkan hasil penelitian factor resiko tentang pola makan, sebagian besar responden memilih sering. Hasil penelitian yang didapatkan sebagian besar anak dengan pola makan yang baik dan mempunyai status gizi norml.

Hasil penelitian factor resiko alergi makanan, sebagian besar responden 
memilih kadang. Alergi makanan adalah gangguan kesehatan yang timbul akibat respon imun spesifik terhadap makanan. Prevalensi alergi makanan pada anak adalah (6\%) Alexander Kam \& Raveinal (2018).

Berdasarkan hasil penelitian factor resiko mencuci tangan terbanyak responden memilih kadang. Menurut Sunardi et al (2017), cuci tangan merupakan teknik dasar yang paling penting dalam pencegahan dan pengontrolan penularan infeksi. Berbanding terbalik dengan hasil penelitian ini yaitu perilaku cuci tangan pada anak usia. sekolah di Kabupatem malang pada kategori baik.

Hasil penelitian factor resiko tentang makan cemilan responden terbanyak memilih kadang. Anak usia sekolah memiliki kebiasaan jajan yang kesehatan dan gizi akan mengancam kesehatan anak sehinggan diperlukan kemampuan anak dalam pemilihan jajanan yang tepat. Adapun hasil penelitian terkait makanan, social ekonomi dan mengenai ketersediaan makanan, responden terbanyak memilih makanan jajanan yang tidak sehat.

Berdasarkan table crosstabulation menunjukkan bahwa gambaran dari crosstabulation tanda dan gejala dan factor resiko dari 149 responden didapatkan

\section{KESIMPULAN}

Berdasarkan hasil penelitian yang dilakukan di Desa Karimbow, Kecamatan Motoling Timur didapati bahwa sebagian besar responden memiliki tanda dan gejala batuk yaitu pada kategori kadang Dan didapati bahwa sebagian besar responden memiliki faktor resiko terpapar asap rokok pada kategori kadang juga.

\section{DAFTAR PUSTAKA}

Bruce. (2015). Konsep anak usia sekolah. Journal of chemical information and modeling,.

Darmawan, A. (2016). Pedoman epidemiologi penyakit menular dan tidak menular. responden yang memiliki factor resiko terpapar asap rokok banyak mengalami tanda dan gejala batuk-batuk. Dampak anak yang terpapar asap rokok pada usia sekolah terhadap kesehatan sama dengan saat anak terpapar pada saat usia bayi, yaitu gangguan pernafasan dan pertumbuhan. Sedangkan dampak spesifik pada periode ini adalah pada perkembangan perilaku anak Jurnal kesehatan Vokasional (2019).

\section{Keterbatasan Penelitian}

Penelitian yang dilakukan oleh peneliti selama Covid-19, yang mengharuskan semuanya untuk bekerja dirumah sehingga terjadi hambatan-hambatan dalam proses pelaksanaan pengambilan data dari responden. Pengambilan data tidak dilakukan secara tatap muka langsung, melainkan menggunakan media internet dengan menggunakan kuesioner yang di taru di dalam google form, dan pengambilan data awal juga hanya dilakukan melalui media sambungan telepon untu proses wawancara. Kesalahan informasi yang disampaikan baik oleh peneliti ataupun responden sangat mungkin terjadi, dikarenakan peneliti hanya dapat mengandalkan data subjektif dari responden tanpa memperhatikan secara objektif keadaan responden.

Dr. H. Masriadi, SKM., S.Pd.I., S.KG. (2016). Epidemiologi penyakit menular. Pengaruh kualitas pelayanan.

Hikmawati, I. (2012). Ilmu Dasar Keperawatan. Yogjakarta : 2012

Iklima, N. (2017). Gambaran pemilihan makanan jajanan pada anak usia sekolah dasar.

Juwantara, R. A. (2019). Analisis teori perkembangan kognitif piaget pada tahap anak usia operasional konkret 712 tahun dalam pembelajaran Matematika. Al-Adzka: Jurnal ilmiah pendidikan Guru Madrasah Ibtidaiyah,.

Kam, A., \& Raveinal, R. (2018). Imunopatogenesis dan implikasi klinis 
alergi makanan pada Dewasa. Jurnal Kesehatan andalas,.

Kurnia, L., Gamayani, U., \& Sadeli, H. A. (2019). Hubungan nyeri kepala primer dengan kualitas hidup pada remaja usia 10-12 tahun di Sekolah Dasar Negeri 077 sejahtera Bandung. Jurnal sistem Kesehatan,

Kurniawati,;Nurullita;Mifbakhudin.(2017)

Indikator pencemaran udara berdasarkan jumlah kendaraan dan kondisi iklim (Studi di wilayah terminal mangkang dan terminal penggaron Semarang). Kesehatan masyarakat,

Leksana, E. (2015). Strategi terapi cairan pada dehidrasi. SMF anestesi dan terapi intensif RSUP Dr Kariadi/Fakultas Kedokteran Universitas Diponegoro, Semarang, Indonesia.

Maryanti, E., Lesmana, S. D., Mandela, H., \& Herlina, S. (2017). Profil penderita diare anak di Puskesmas Rawat Inap Pekanbaru. Jurnal Ilmu Kedokteran, .

Masyarakat, K., \& Metabolik, S. (2019). Jurnal persada husada Indonesia determinan insiden sindrom metabolik menurut gender determinant of metabolic syndrome incidenceb by gender abstrak pendahuluan metode data tentang sindrom metabolik didapat.

Maulana Fakh, I., Novialdi N., \& Elmatris, E. (2016). Karakteristik pasien tonsilitis kronis pada anak di bagian THT-KL RSUP Dr. M. Djamil Padang. Jurnal Kesehatan Andalas, .

Pangemanan, B., Widodo, D., \& Widiani, E. (2017). Nursing news volume 4, nomor 1, 2019.

Purwanto, I. F., Imandiri, A., \& Arifanti, L. (2018). Combination of acupuncture therapy and turmericliquorice herbs for chronic coughing case. Journal of vocational health studies.

Rachmawati, A., \& Kartika, L. (2020). Pengetahuan Ibu dan pengelolaan demam anak di satu rumah sakit swasta di Indonesia Barat. Jurnal
Keperawatan Raflesia.

Rahman, H. F., Widoyo, S., Siswanto, H., \& Biantoro, B. (2016). Factors related to diarrhea in solor village cermee district bondowoso.

Belladonna M. (2018). Hubungan paparan inhalasi karbon monoksida dengan fungsi penghidup. (Jurnal Kedokteran Diponegoro).

Sari, G. Lubis. G \& Edison E. (2016). Hubungan pola makan dengan status gizi anak usia 3-5 tahun di Wilayah Kerja Puskesmas Nanggalo Padang 2014.

Sefrina A. Nurhaeni, N. Hayati, H. Cilacap A. S. Keperawatan, F. I. Indonesia, U., Keperawatan, F. I. \& Indonesia U. (2010).

Sunardi, \& Ruhyanuddin, F. (2017). The impact of hand washing on the incident of diarrhea among SchoolAged children at the district of Malang. Jurnal Keperawatan.

Supit, G. M. A., Tumbel, R. E. C., \& Tamus, A. Y. (2016). Kesehatan telinga pada masyarakat di komplek TNI Manado. E-CliniC.

Syafa'at, A. (2015). Gambaran gangguan pola tidur pada anak. Gambaran Gangguan Pola Tidur Pada Anak Usia 9-12 Tahun.

Wahyuni, D. \& Indriyani, I. (2019). faktorfakyot yang berhubungan dengan kelelahan kerja pada pekerja. Jurnal Ilmiah Kesehatan.

Wibowo, W. J., Wahid, T. O. R., \& Masdar, H. (2020). Hubungan onset keluhan nyeri perut dan jumlah leukosit dengan tingkat keparahan apendisitis akut pada anak. Health \& Medical Journal. 